\title{
Does Total Rewards Reduce the Core Employees' Turnover Intention?
}

\author{
Zhoutao Cao ${ }^{1}$, Jinxi Chen ${ }^{1} \&$ Yixiao Song ${ }^{1}$ \\ ${ }^{1}$ School of Business Administration, South China University of Technology, Guangzhou, China \\ Correspondence: Jinxi Chen, School of Business Administration, South China University of Technology, \\ Guangzhou, China. E-mail: chenjinxisi@gmail.com
}

Received: June 13, 2013

Accepted: August 14, 2013

Online Published: September 22, 2013

doi:10.5539/ijbm.v8n20p62

URL: http://dx.doi.org/10.5539/ijbm.v8n20p62

\begin{abstract}
The turnover of core employees is great lost for industrial companies, so that the research of turnover Intention (TI) is critical to enterprise. Recently, the researches discuss the factors that affect turnover invention from different views. Based on the concept of total rewards (TR) we go deep into the influencing factors. In this paper, we used ULR and hierarchical regression analysis to build model with organizational justice (OJ) as moderator variable. Results showed that the five elements of total rewards, salary, rewards, work-life, performance \& recognition and development \& career are negative to employees' turnover intention. Secondly, distribute justice and interactional justice significantly negative moderate the relationship of TR and TI. However, process justice only has significantly negative moderating effect on work-life balance and development \& career to TI, while the negative effect of salary, welfare and performance are not significant.
\end{abstract}

Keywords: core employee, total rewards, organizational justice, turnover intention

\section{Introduction}

In the last few years, due to Chinese inland economic development and the support policy to the agriculture, the recruitment difficulties of manufacturers in Pearl River Delta become increasingly prominent. It caused scholars' attention on the thinking and research about the influencing factors of turnover. The traditional rewards are changing, from based on the qualifications and record of service to performance, from monetary rewards to non-monetary rewards, from external to internal, from fixed to float, from unified to different, and from independent rewards to coordinate rewards (Chen \& Hsieh, 2006). Yao et al (2005) has confirmed that the total remuneration level, long-term accumulation and capability salary have a significant impact on the satisfaction, and long-term incentive to have a significant impact on turnover intention (TI) in the research on the effect of the pay system. At the same time, corporate remuneration system needs reform and improvement. One way is a comprehensive remuneration system (Yao \& Fang, 2005).

A good remuneration system can motivate employees, thereby reducing the intention of looking for other jobs and turnover (Wanous, 1974; Shi, 1991).As an incentive for companies, employee benefits play a unique role in attracting and retaining talents. Benefits satisfaction as a feeling and evaluation of the employees to the corporate welfare system will have an important impact on employees' attitudes and behavior (Danehower \& Lust, 1996). From the perspective of the development of human resources practice, organizations take actions which are conducive to the development of employees will enhance the motivation of the staff to make positive reciprocal behaviors (Settoon, Bennett \& Liden, 1996). For example, inner career development implies more meaningful tasks, more responsibility and autonomy, which presents the investment in employee development, and to provide staff with the opportunities. In addition, performance evaluation, especially the performance feedback, which is reported to the evaluated object, not only reflects the importance attention on the employees, and also provides the basis for performance improvement and development (He, Yuan \& Peng, 2011). Strategic human resource management theory has showed the correlation of high investment in human resource systems and employee turnover intention was significantly negative (Arthur, 1994; Guthrie, 2001; Batt, 2002).

In the past, scholars have pointed out, from different views, that pay, benefits, work-family conflict, achievement motivation and development inputs are important factors which affect employee turnover intention. In this paper, we will introduce a more comprehensive concept - total rewards - to establish the theoretical study framework of the effect of various dimensions on turnover intention. Wen et al pointed out that, comparing with the traditional concept of total rewards, the change is not the proportion of welfare, but expanding the concept of income (Wen, Gao \& Lv, 2007). Foreign scholars pioneered the concept of total 
rewards, but less study focus on the main cause of turnover intention. While Chinese scholars mainly focused on the pay as the reasons of employee turnover, ignoring the effect of non-monetary benefits. Enterprises survived by the efforts of the staff, and the staff hopes to get their due reward through their own efforts, therefore organizational justice is a moderator variable in this relationship. We attempt to find the key influencing factors through the study on various dimensions of total rewards and employee turnover in the Pearl River Delta manufacturers, with variable organizational justice.

\section{Literature Review}

\subsection{Relevant Concept}

Researches on total rewards management are earliest originated from the 1970s in the United States. And now, there have been more and more enterprises begin to use total rewards as a guide in the management practices. For example, the well-known companies IBM, has been working to implement a total rewards management from the mid-1990s (Liu, 2005). Total rewards practice have pointed out the strategic policy of reward for many companies (Egan, 2011). From the theoretical view, traditional design and processes often leads to rigid payment system, which cannot effectively motivate employees, and result in low employee morale (Heneman \& Lebianc, 2001). Therefore, enterprises must focus on four important motivating factors to win the future talent competition: company's growth prospects, opportunities of personal growth, a good working environment and a total rewards system (Zingheim \& Schuster, 2003). Core employees' motivations include the following categories: salary, welfare, personal growth and development, challenging work and company's growth prospects. And the incentive approach includes: monetary, the right and training incentives (Zhao \& Shi, 2006). The researches on the incentive ways and factors of core employees have made many achievements, but less concentrated in systematic analysis on the impact of core employees' turnover intention, and mainly by qualitative researches. We attempt to find the key influence factors of total rewards on employee turnover intention in the Pearl River Delta manufacturing, and the moderating effect of organizational justice, by studying the impact effect of various dimensions of total rewards on employees' turnover intention.

\subsubsection{Core Employee}

The core employees are the key and essential persons for companies to achieve the operation and success. They are hard to seek and replace, and valued by company (Branham, 2000). Their jobs require long-time education and training, high skill, abundant experience in their industry and excellent ability of operation and management (Zhang \& He, 2001). The study shows that the performance of $20 \%$ employees who participate more, have more skills and perform better in the company are triple higher than the rest (Zingheim \& Schuster, 2006). Thus, we refer core employee of the enterprise to the ones with higher education, higher professional skills and a wealth of experience in the industry and core business, and control critical resources.

\subsubsection{Total Rewards}

Total reward is an employee-oriented holistic remuneration design system. It expands the content of the traditional reward which is regarded as high-price welfare project (Giancola, 2009). Tropman (2002) proposed the total rewards concept from the business practices and personal study. He believes that the traditional pay system has been unable to attract, retain and motivate the modern employees. Total rewards includes not only simply the salary, or monetary benefits, but also dozens of spiritual incentives, such as an excellent work conditions, a good working atmosphere, training and promotion opportunities (Tropman , 2002). Liu (2004) divided total rewards into 4 parts, from inside to outside: salary, welfare, career and environment. While Giancola (2009) simplify the total rewards into five parts: remuneration, welfare, work-life balance, performance /appreciated and development or career opportunity.

In fact, total rewards is a good interactive system of return on investment, it is always highlighted the win-win thought of coordinating and maximizing the interests of business and individual. Each organization has different rewards systems; however, total rewards are not merely the salary and welfare (Zingheim \& Schuster, 2006). It's a comprehensive unified program that consist all parts of rewards (Armstrong \& Stephens, 2005). Total rewards make chance for employees to get the knowledge and learn new skills, which promote their future career (Ludlow \& Farrell, 2010). We will divide total rewards into following core factors: monetary external remuneration (remuneration, welfare), non-monetary external remuneration (performance or appreciated), and inherent remuneration (work-life balance and development or career opportunities).

\subsubsection{Organizational Justice}

Organizational justice refers to the justice experience of the employees in organizations. In the current study, distributive justice and process justice dimension of organizations justice have been widely recognized. While 
the dimension interactional justice, although there is a dispute, but also caused attention. Combined Homans' social exchange theory and Festinger's cognitive dissonance theory, Adams (1965) proposed the well-known distributive justice theory. The theory pointed out that the employees not only care about the absolute justice of the allocation results, they are more concerned with the relative justice of allocation results. When employees feel unfair, they may choose to depart from the situation.

Thibaut \& Walker (1975) proposed the process justice theory after the study on court proceedings. Process justice theory is to investigate the reaction of the employees for the process, including process control and decision-making control. Process control refers to the individual gives the conducive proof to their own goals in the dispute settlement process; decision-making control refers to the individual has the opportunity to express their views on the controversial decision to play a controlling role in the final decision-making.

In addition, Bies \& Moag (1986) found that there is a very important area in organizational justice which is not being taken seriously, that is interactional justice. They believe that the interaction between employees and managers will affect employees' sense of organizational justice. Employees will experience the managers is whether to treat them fairly during the exchanges in peacetime, for example, whether managers respect them and whether they treat them. Their study better explain the interaction relationship of organizational justice. Yang (1993) pointed out that the Chinese culture is the culture of the familism, then the interactional justice related with leadership is more important significant in the context of Chinese culture.

In this paper, the organizational justice refers to employees in the organization believe that the results of salary distribution are reasonable, the allocation process is reasonable, and whether they are interpersonal treated fairly in the remuneration allocation process, according to make judgments. Based on the theories above, we divide organizational justice into three dimensions: distributive justice, process justice and interactional justice.

\subsubsection{Turnover Intention}

Employee turnover refers to the termination of the relationship that individual members gain from organizatio. Price (1977) consider that there are two types of employee turnover behaviors, voluntary and involuntary, and that the former is mainly initiated by the employees themselves, while the latter are mostly initiated by the company's management decided to terminate the employment relationship. Dalton \& Todor (1979) further pointed out that the voluntary turnover can be divided into functional and dysfunctional. In general, functional turnover can be the forecast and control, so we explore the core employee turnover from the view of voluntary functional turnover.

Many scholars do the research on the formation of the TI from different views. No doubt the reward is the most important factor of satisfaction and turnover (Zhou \& Yang, 2012).

In the case of the Pearl River Delta manufacturing, the main reasons that affect the loss of core employees include: (1) personal factors, including salary, the lack of effective incentive and development space; (2) business factors, including the defects of organizational structure, improper organizational goals, and the inappropriate powers and responsibilities. Especially prominent human resource management issues, such as the rigid employment mechanism, improper recruitment, inadequate training and incentive system is not perfect, that affect the core employees' TI. This paper attempts to explain the influencing factors of TI by introducing the more comprehensive and specific concepts - total rewards.

\subsection{Hypotheses and Research Design}

\subsubsection{Total Rewards and Employees' TI}

Many scholars found that the various aspects of total rewards contained are the key variables that affect employee TI. Total rewards provide employees with good work environment as well as development and career opportunities. It can significantly increase the employees' retention rate and productivity (Ludlow \& Farrell, 2010; Nazir, Shah, \& Zaman, 2012). Liu et al (2006) supposed that the there are five crucial influencing factors of TI: work content, promotion system, salary, subjective perception about the selectable jobs and affective commitment.

For the employees in the Pearl River Delta manufacturing, remuneration, welfare and performance represent the personal success and value. When income or the increase is not satisfied, the employee will have intent to depart, even lead to the turnover behavior. The job of high autonomy can lead employee to emerge endogenous satisfaction (Gouldner, 1954). And make employees feel the challenge of the work and be motivated (Hackman \& Oldham, 1980). Work-life balance has become the academics focus ( Eikhof, Warhurst \& Haunschild, 2007). If employees spend more energy and time on the job, they cannot take into account the life, and the employee's job performance is bound to decline. At the same time, they may also be lack of family support, then TI generate. 
Now, balance the needs of the work and personal life is considered to be the world's important issue (Noor, 2011).

Eisenberger, et al (1986) supposed that the support to the development employees feel from the organization will affect their expectations to organization in many aspects. Rhoades \& Eisenberger (2002) also proved this opinion, because if the organization is unable to provide career development support to employees, the result will be the employees' turnover behavior. Zhang \& Zhang (2007) showed that the personal opportunities of technology development and career development direction is an important influencing factors of employee turnover, conversion costs and career growth opportunities was significantly negatively correlated with TI. Promotions opportunities help reduce employees' TI through making employees feel the possibility of the increase in income and welfare. High opportunity for promotion can encourage individual career development in the organization, and it can ensure the security of the work and other long-term future earning (such as income, rights, and status), that are deemed to reduce TI (Halaby, 1986). Zhang \& Zhang (2007) pointed out that the income distribution is negative correlation with promotion justice, learning and career development opportunities and managers' TI. So, we propose:

$\mathrm{H1}$ : Remuneration is negatively correlated with employees' TI;

$\mathrm{H} 2$ : Welfare is negatively correlated with employees' TI;

H3: Work-life Balance is negatively correlated with employees' TI;

H4: Performance/Appreciated is negatively correlated with employees' TI;

H5: Development or Career Opportunity is negatively correlated with employees' TI.

\subsubsection{Organizational Justice and Employees' TI}

We found that these five dimensions above affect employee turnover invention through the sense of organization justice. Organizational justice reflect an environment of fair competition, it is a very important variables of organizational effectiveness affecting employees' psychology and behaviors. Employees' sense of unfairness will reduce organizational satisfaction and organizational commitment, thereby increasing TI. Numerous studies showed that organizational justice was negatively correlated with TI. For example, Zhang \& Wang (2003) confirmed the internal justice influenced on turnover of managers. Jiang (2007) found that the distributive justice and process justice have a significant impact on organizational commitment and TI by perceived organizational support. Gabris \& Ihrke (2001) confirm the relation between organizational justice and job satisfaction through employees' perception of performance evaluation. And many studies have shown that job satisfaction and turnover are negatively related (Muchinsky \& Morrow, 1980; Bentein et al., 2005). So we selected organizational justice as a moderator variable in this paper.

Distributive justice refers to the degree of incentive to work and their performance in the organization. In the enterprise, work more and gain more is the reflection of distributive justice. Studies have shown that the distributive justice can affect employee satisfaction more than the amount of return (Knowles, 1964). So we propose followings:

H6-1: Distributive justice negatively moderates the effect of remuneration to employees' TI;

H6-2: Distributive justice negatively moderates the effect of welfare to employees' TI;

H6-3: Distributive justice negatively moderates the effect of work-life balance to employees' TI;

H6-4: Distributive justice negatively moderates the effect of performance/ appreciated to employees' TI;

H6-5: Distributive justice negatively moderates the effect of development or career opportunity to employees' TI.

Because distributive justice ignores the procedures before the distributive results, Thibaut \& Walker (1975) proposed the concept of process justice. The process justice stressed the decisions is whether made by full collection of objective facts during organizations' decision making and judgment, this justice activity will directly affect the level of trust and organizational commitment of the members in the organization (Leventhal, 1980). Employees expect organizations to use the existing rules and regulations to regulate the work behaviors fairly. If they feel the allocation process is fair, then the motives of turnover would be greatly reduced. So, we propose:

H6-6: Process justice negatively moderates the effect of remuneration to employees' TI;

H6-7: Process justice negatively moderates the effect of welfare to employees' TI; 
H6-8: Process justice negatively moderates the effect of work-life balance to employees' TI;

H6-9: Process justice negatively moderates the effect of performance/ appreciated to employees' TI;

H6-10: Process justice negatively moderates the effect of development or career opportunity to employees' TI.

Interaction justice, which is the sense of interpersonal treated fairness that employee feels from decision makers during the remuneration decision-making process. Combined with employees' interviews, we found, in the enterprise, the sense of fairness from the comparing with others at same level has important moderate effect in addition to the salary. At the same time, during the welfare and performance defined process, whether treated politely and interactive participate, also affect employees' motivation to some extent, thereby affecting the TI. So, we propose:

H6-11: Interactional justice negatively moderates the effect of remuneration to employees' TI;

H6-12: Interactional justice negatively moderates the effect of welfare to employees' TI;

H6-13: Interactional justice negatively moderates the effect of work-life balance to employees' TI;

H6-14: Interactional justice negatively moderates the effect of performance/ appreciated to employees' TI;

H6-15: Interactional justice negatively moderates the effect of development or career opportunity to employees' TI.

Accordingly, we propose following model (Figure1):

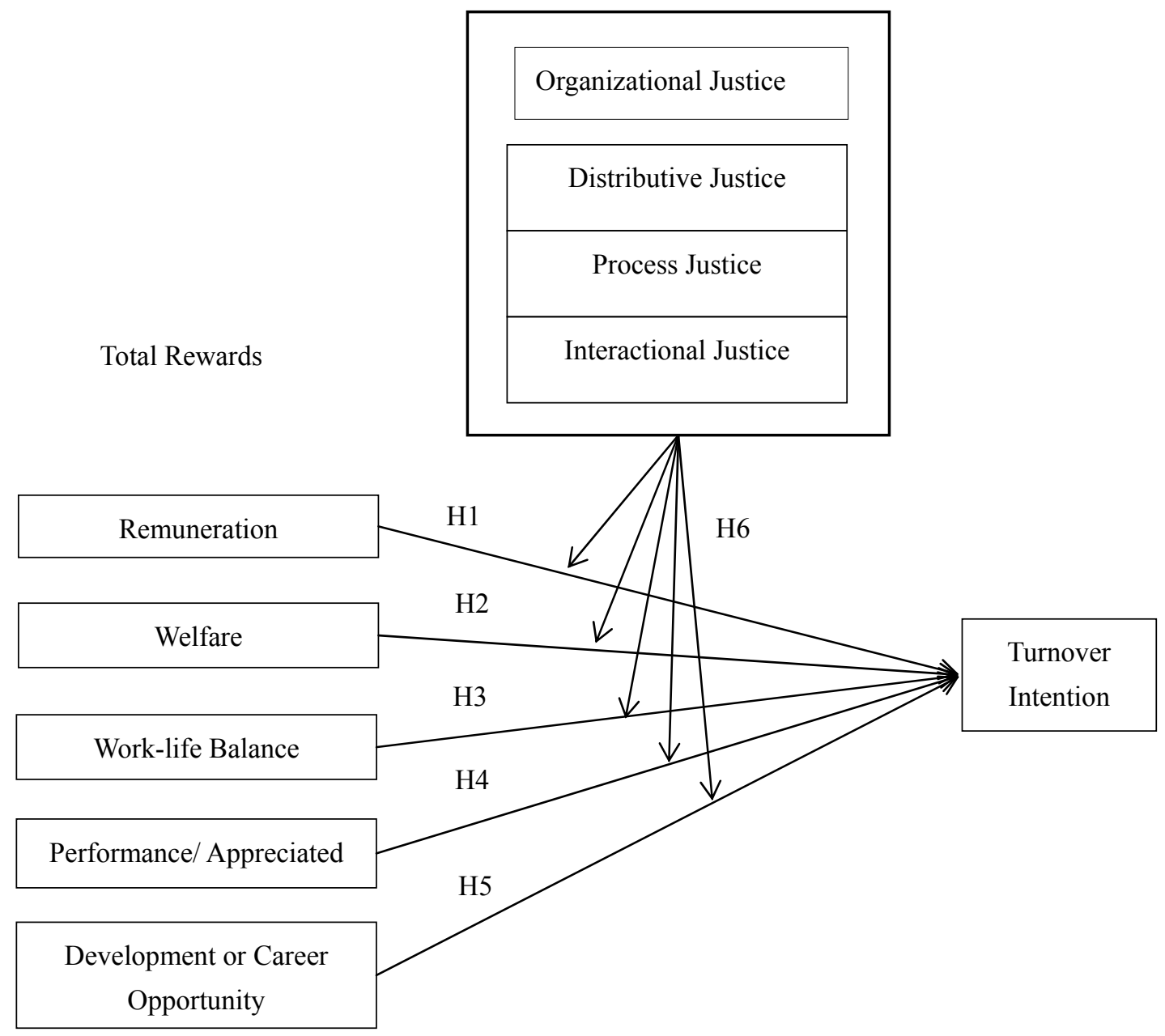

Figure 1. Model of the effect of total rewards to employees' TI through organizational justice

The questionnaires aim to the company's core employees who have expertise and a wide range of external relations or management skills in the enterprise, including top management decision-makers, middle managers, 
and engineers. They play an increasingly important role in the future competition, because they have scarce resources in the enterprise, and their turnover will make organizations many losses.

\section{Results}

We got the sample and data by issuing questionnaire online and visiting. At last, total 450 questionnaires issued, actually 397 retrieve, the response rate was $88.22 \%$, of which 356 valid questionnaires, the effective response rate of $79.11 \%$. The result we can see in Table 1 . In education level, the overall research objects have generally high education, with $67.1 \%$ is bachelor's and above. At classification of work department, manufacturing and quality are respectively $20.8 \%$ and $23.9 \%$, the rest is the engineering, $R \& D$, supply and transport, administration, financial and others. Most employees' monthly income is between CNY3000-6000.

\subsection{Variable Measures}

In order to ensure the validity of the questionnaire design, we use measurement scale and items universally accepted by related research, and correct some questions in accordance with the China's context and the actual situation. Cronbach's $\alpha$ coefficient of these variables terms and their sub-dimensions is higher than 0.7 , showing a high level of reliability of the questionnaire. It fits the requirements of reliability testing. The results of each variable are shown in the Table 2.

Table 1. The feature of samples

\begin{tabular}{|c|c|c|c|}
\hline \multicolumn{2}{|l|}{ Item } & Amount & Per $(\%)$ \\
\hline \multirow{2}{*}{ Gender } & Male & 224 & 62.9 \\
\hline & Female & 132 & 37.1 \\
\hline \multirow{5}{*}{ Age } & $<20$ & 0 & 0 \\
\hline & $21-30$ & 256 & 71.9 \\
\hline & $31-40$ & 85 & 23.9 \\
\hline & $41-50$ & 11 & 3.1 \\
\hline & $>51$ & 4 & 1.1 \\
\hline \multirow{4}{*}{ Education } & High school or under & 38 & 10.7 \\
\hline & Junior college & 79 & 22.2 \\
\hline & Bachelor & 198 & 55.6 \\
\hline & Master or above & 41 & 11.5 \\
\hline \multirow{8}{*}{ Department } & Manufacturing & 74 & 20.8 \\
\hline & Engineering & 44 & 12.4 \\
\hline & $\mathrm{R} \& \mathrm{D}$ & 24 & 6.7 \\
\hline & Supply and Transport & 35 & 9.8 \\
\hline & Quality & 85 & 23.9 \\
\hline & Administration & 63 & 17.7 \\
\hline & Financial & 24 & 6.7 \\
\hline & Others & 7 & 2.0 \\
\hline \multirow{4}{*}{ Hierarchy } & Common employee & 97 & 27.2 \\
\hline & Front-Line Managers & 133 & 37.4 \\
\hline & Middle managers & 89 & 25.0 \\
\hline & Top managers & 37 & 10.4 \\
\hline \multirow{3}{*}{ Years of working at present company } & $<1$ & 101 & 28.4 \\
\hline & $1-3$ & 85 & 23.9 \\
\hline & $3-5$ & 96 & 27.0 \\
\hline \multirow{5}{*}{ Income (CNY/month) } & $>5$ & 74 & 20.7 \\
\hline & $<3000$ & 105 & 29.4 \\
\hline & $3000-6000$ & 133 & 37.4 \\
\hline & $6000-15000$ & 86 & 24.2 \\
\hline & $>15000$ & 32 & 9.0 \\
\hline \multicolumn{2}{|c|}{ Total } & 356 & 100 \\
\hline
\end{tabular}


Table 2. Cronbach's $\alpha$ coefficient of variables

\begin{tabular}{|c|c|c|c|c|}
\hline \multicolumn{2}{|r|}{ Variables } & \multicolumn{2}{|c|}{ deleted Cronbach's $\alpha$ coefficient } & \multirow{2}{*}{$\begin{array}{c}\text { Test Results } \\
\text { pass }\end{array}$} \\
\hline \multirow{5}{*}{$\begin{array}{l}\text { Total Rewards } \\
\text { (33) }\end{array}$} & Remuneration (5) & & 0.889 & \\
\hline & Welfare (5) & & 0.885 & pass \\
\hline & Performance /Appreciated (4) & 0.897 & 0.887 & pass \\
\hline & Work-life Balance (8) & & 0.891 & pass \\
\hline & Development or Career Opportunities (11) & & 0.890 & pass \\
\hline \multirow{3}{*}{$\begin{array}{l}\text { Organizational } \\
\text { Justice (19) }\end{array}$} & Distributive Justice (9) & & 0.914 & pass \\
\hline & Process Justice (3) & 0.917 & 0.909 & pass \\
\hline & Interactional Justice (7) & & 0.916 & pass \\
\hline \multicolumn{2}{|c|}{ Turnover Intention (5) } & \multicolumn{2}{|c|}{0.886} & pass \\
\hline \multicolumn{2}{|l|}{ All items (57) } & \multicolumn{2}{|c|}{0.953} & pass \\
\hline
\end{tabular}

The items in the questionnaire are based on the related theories and literature and the questionnaire of other scholars, and modify with the assessment of relevant experts in the field and pre-test, therefore, it should have a certain degree of content validity. We use factor analysis to estimate construct validity. The KMO of total rewards is 0.908 , significance probability of Bartlett test is $0.000(* * *)$, each measuring item in the corresponding factor is greater than 0.5 . The KMO of organizational justice is 0.907 , significance probability of Bartlett test is $0.000(* * *)$, each measuring item in the corresponding factor is greater than 0.5 . The KMO of TI is 0.903 , significance probability of Bartlett test is $0.000(* * *)$, each measuring item in the corresponding factor is greater than 0.5 . Therefore, the total rewards, organizational justice and TI scales all have good validity.

\subsection{Correlation Test}

The correlation analysis is the statistical methods commonly used to test the correlation between variables, so we used Pearson correlation analysis. The results are shown in the following Table 3.

Table 3. Statistical description and the correlation between the variables

\begin{tabular}{|c|c|c|c|c|c|c|c|c|c|}
\hline & 1.1 & 1.2 & 1.3 & 1.4 & 1.5 & 2.1 & 2.2 & 2.3 & 3 \\
\hline 1.1 Remuneration & 1 & & & & & & & & \\
\hline 1.2 Welfare & $0.707^{* *}$ & 1 & & & & & & & \\
\hline $\begin{array}{l}\text { 1.3 Performance/ } \\
\text { Appreciated }\end{array}$ & $0.444^{* *}$ & $0.519^{* *}$ & 1 & & & & & & \\
\hline $\begin{array}{l}1.4 \text { Work-Life } \\
\text { Balance }\end{array}$ & $0.485^{* *}$ & $0.575^{* *}$ & $0.631^{* *}$ & 1 & & & & & \\
\hline $\begin{array}{l}\text { 1.5 Development or } \\
\text { Career Opportunity }\end{array}$ & $0.508^{* *}$ & $0.535^{* *}$ & $0.530^{* *}$ & $0.610^{* *}$ & 1 & & & & \\
\hline $\begin{array}{l}2.1 \text { Distributive } \\
\text { Justice }\end{array}$ & $0.391^{* *}$ & $0.449^{* *}$ & $0.505^{* *}$ & $0.391^{* *}$ & $0.542^{* *}$ & 1 & & & \\
\hline 2.2 Process Justice & $0.390^{* *}$ & $0.463^{* *}$ & $0.476^{* *}$ & $0.404^{* *}$ & $0.507^{* *}$ & $0.689^{* *}$ & 1 & & \\
\hline $\begin{array}{l}2.3 \text { Interactional } \\
\text { Justice }\end{array}$ & $0.462^{* *}$ & $0.520^{* *}$ & $0.556^{* *}$ & $0.530^{* *}$ & $0.483^{* *}$ & $0.576^{* *}$ & $0.780^{* *}$ & 1 & \\
\hline $3 \mathrm{TI}$ & $-0.534^{* *}$ & $-0.600^{* *}$ & $-0.608^{* *}$ & $-0.613^{* *}$ & $-0.552^{* *}$ & $-0.538^{* *}$ & $-0.630^{* *}$ & $-0.734^{* *}$ & 1 \\
\hline Mean & 3.6961 & 3.6078 & 3.3956 & 3.3617 & 3.3495 & 3.3029 & 3.3558 & 3.4068 & 2.5330 \\
\hline SD & 0.701 & 0.599 & 0.712 & 0.637 & 0.624 & 0.564 & 0.613 & 0.617 & 0.617 \\
\hline
\end{tabular}

Sample Size $=356,{ }^{* * *} \mathrm{p}<0.001,{ }^{* *} \mathrm{p}<0.01,{ }^{*} \mathrm{p}<0.05$.

The analysis results show a significant correlation between the variables and the correlation coefficients are all less than 0.9 , there is no collinearity among the variables. 


\subsection{Statistics and Data Analysis}

We use unary linear regression analysis, and establish the regression model with the independent variable remuneration, welfare, work-life balance, performance/appreciated and development or career opportunities and the dependent variable $\mathrm{TI}$ to, then test $\mathrm{H} 1, \mathrm{H} 2, \mathrm{H} 3, \mathrm{H} 4$ and $\mathrm{H} 5$.

Table 4 shows, the significant value Sig of regression analysis that remuneration, benefits, work-life balance, performance or appreciated, development or career opportunity respectively for independent variables with TI as dependent variable all is 0.000 , less than 0.001 . It indicates regression have passed the test, the regression coefficients are $-0.470,-0.546,-0.526,-0.593,-0.618$, therefore, it can be seen that the remuneration, benefits, work-life balance, performance or appreciated and development or career opportunities exist significant negative correlation with TI, H1, H2, H3, H4, H5 were all passed.

Table 4. The regression result of five dimension of total rewards and TI

\begin{tabular}{cccccc}
\hline Items & $\mathrm{R}^{2}$ & Beta & $\mathrm{t}$ & $\mathrm{F}$ & $\mathrm{Sig}$ \\
\hline Remuneration to TI & 0.281 & -0.470 & 7.771 & 19.258 & 0.000 \\
Welfare to TI & 0.301 & -0.546 & 8.176 & 20.410 & 0.000 \\
Work-Life Balance to TI & 0.366 & -0.526 & 6.846 & 24.351 & 0.000 \\
Performance or Appreciated to TI & 0.372 & -0.593 & 8.704 & 25.625 & 0.000 \\
Development or Career Opportunity to TI & 0.357 & -0.618 & 7.559 & 23.645 & 0.000 \\
\hline
\end{tabular}

\subsection{Moderating Effect}

We used hierarchical regression analysis method for the dependent and independent variables are continuous variables. We respectively test the regulated effect of distributive justice, process justice and interactional justice, the steps as following: (1) run a regression of $\mathrm{Y}$ (dependent variable), $\mathrm{X}$ (independent variable) and $\mathrm{M}$ (moderator variable), and the coefficient of determination is $\mathrm{R}_{12}$; (2) run a regression of $\mathrm{Y}, \mathrm{X}, \mathrm{M}$ and $\mathrm{XM}$ (interaction variable of independent variable and moderator variable), and the coefficient of determination is $\mathrm{R}_{22}$; (3) compare $R_{12}$ and $R_{22}$, if $R_{22}$ significantly higher than $R_{12}$, the moderating effect is significant. Results are shown in Table 5-7.

Table 5 shows, in the regulation analysis of Distributive Justice between remuneration and TI, $\mathrm{R}_{1}{ }^{2}$ is $0.413, \mathrm{R}_{2}{ }^{2}$ is 0.427 , regulated effect is significant; in the regulation analysis of Distributive Justice between welfare and TI, $\mathrm{R}_{1}{ }^{2}$ is $0.385, \mathrm{R}_{2}{ }^{2}$ is 0.432 , regulated effect is significant; in the regulation analysis of Distributive Justice between work-life balance and TI, $\mathrm{R}_{1}{ }^{2}$ is $0.441, \mathrm{R}_{2}{ }^{2}$ is 0.462 , regulated effect is significant; in the regulation analysis of Distributive Justice between performance or appreciated and TI, $R_{1}{ }^{2}$ is $0.480, R_{2}{ }^{2}$ is 0.487 , regulated effect is significant; in the regulation analysis of Distributive Justice between development or career opportunity and TI, $\mathrm{R}_{1}{ }^{2}$ is $0.467, \mathrm{R}_{2}{ }^{2}$ is 0.478 , regulated effect is significant. Thus, H6-1, H6-2, H6-3, H6-4, H6-5 are passed. Table 6 shows in the regulation analysis of Process Justice between remuneration and TI, $R_{1}{ }^{2}$ is $0.495, R_{2}{ }^{2}$ is 0.496 , but, introduce the interaction of remuneration and process justice as the third variable into the regression equation, $\mathrm{P}>0.05, \mathrm{~F}<10, \mathrm{~b}=0.131$. It shows the interaction of remuneration and process justice was not significant, so regulated effect is not significant; in the regulation analysis of Process Justice between welfare and TI, $\mathrm{R}_{1}{ }^{2}$ is $0.470, \mathrm{R}_{2}{ }^{2}$ is 0.477 , but, introduce the interaction of welfare and process justice as the third variable into the regression equation, $\mathrm{P}>0.05, \mathrm{~F}<10, \mathrm{~b}=0.096$. It shows the interaction of welfare and process justice was not significant, so regulated effect is not significant; in the regulation analysis of Process Justice between work-life balance and TI, $\mathrm{R}_{1}{ }^{2}$ is $0.519, \mathrm{R}_{2}{ }^{2}$ is 0.537 , regulated effect is significant; in the regulation analysis of Process Justice between performance or appreciated (P/A) and TI, $\mathrm{R}_{1}{ }^{2}$ is $0.550, \mathrm{R}_{2}{ }^{2}$ is 0.559 , but, introduce the interaction of $\mathrm{P} / \mathrm{A}$ and process justice as the third variable into the regression equation, $\mathrm{P}>0.05, \mathrm{~F}<10, \mathrm{~b}=0.143$. It shows the interaction of $\mathrm{P} / \mathrm{A}$ and process justice was not significant, so regulated effect is not significant; in the regulation analysis of Process Justice between development or career opportunity and TI, $\mathrm{R}_{1}{ }^{2}$ is $0.518, \mathrm{R}_{2}{ }^{2}$ is 0.535 , regulated effect is significant. Thus, H6-8, H6-10 are passed, H6-6, H6-7, H6-9 are not passed.

Table 7 shows, in the regulation analysis of Interactional Justice between remuneration and TI, $\mathrm{R}_{1}{ }^{2}$ is $0.521, \mathrm{R}_{2}{ }^{2}$ is 0.579 , regulated effect is significant; in the regulation analysis of Interactional Justice between welfare and TI, $\mathrm{R}_{1}{ }^{2}$ is $0.590, \mathrm{R}_{2}{ }^{2}$ is 0.634 , regulated effect is significant; in the regulation analysis of Interactional Justice between work-life balance and TI, $\mathrm{R}_{1}{ }^{2}$ is $0.597, \mathrm{R}_{2}{ }^{2}$ is 0.623 , regulated effect is significant; in the regulation analysis of Interactional Justice between performance or appreciated and TI, $\mathrm{R}_{1}^{2}$ is $0.609, \mathrm{R}_{2}^{2}$ is 0.638 , 
regulating effect is significant; in the regulation analysis of Interactional Justice between development or career opportunity and TI, $\mathrm{R}_{1}{ }^{2}$ is $0.604, \mathrm{R}_{2}{ }^{2}$ is 0.638 , regulated effect is significant. Thus, H6-11, H6-12, H6-13, H6-14, H6-15 are passed.

Table 5. The moderating effect of distributive justice on relation of total rewards and TI

\begin{tabular}{cllcccc}
\hline & Step one & Step two & Step three & F & R2 & D R2 \\
\hline & $-0.470^{* *}$ & & & 19.258 & 0.281 & 0.281 \\
Remuneration & $-0.336^{* *}$ & $-0.425^{* *}$ & & 16.342 & 0.413 & 0.132 \\
& $-0.887^{* *}$ & $-1.04^{* *}$ & $-0.174^{* *}$ & 15.268 & 0.427 & 0.014 \\
& $-0.546^{* *}$ & & & 20.41 & 0.301 & 0.301 \\
Welfare & $-0.365^{* *}$ & $-0.369^{* *}$ & & 17.635 & 0.385 & 0.084 \\
& $-1.564^{* *}$ & $-1.615^{* *}$ & $-0.378^{* *}$ & 15.198 & 0.432 & 0.047 \\
Work-life Balance & $-0.526^{* *}$ & & & 24.351 & 0.366 & 0.366 \\
& $-0.391^{* *}$ & $-0.339^{* *}$ & & 23.95 & 0.441 & 0.075 \\
Performance & $-1.142^{* *}$ & $-1.104^{* *}$ & $-0.233^{* *}$ & 20.862 & 0.462 & 0.021 \\
/Appreciated & $-0.593^{* *}$ & & & 25.625 & 0.372 & 0.372 \\
Development or & $-0.460^{* *}$ & $-0.385^{* *}$ & & 23.872 & 0.48 & 0.108 \\
Career & $-0.930^{* *}$ & $-0.851^{* *}$ & $-0.145^{* *}$ & 21.902 & 0.487 & 0.007 \\
Opportunities & $-0.468^{* *}$ & & & 23.645 & 0.357 & 0.357 \\
\hline
\end{tabular}

${ }^{* * *} \mathrm{p}<0.001,{ }^{* *} \mathrm{p}<0.01,{ }^{*} \mathrm{p}<0.05$.

Table 6. The Moderating Effect of Process Justice on relation of Total Rewards and TI

\begin{tabular}{clllrrr}
\hline & Step one & Step two & Step three & \multicolumn{1}{c}{ F } & R2 & D R2 \\
\hline & $-0.470^{* *}$ & & & 19.258 & 0.285 & 0.285 \\
& $-0.299^{* *}$ & $-0.400^{* *}$ & & 10.381 & 0.495 & 0.21 \\
Remuneration & $-0.527^{* *}$ & $-0.521^{* *}$ & 0.131 & 6.86 & 0.496 & 0.001 \\
& $-0.546^{* *}$ & & 20.41 & 0.301 & 0.301 \\
& $-0.309^{* *}$ & $-0.474^{* *}$ & & 13.912 & 0.47 & 0.169 \\
Welfare & $-0.146^{* *}$ & $-0.117^{* *}$ & 0.096 & 6.695 & 0.477 & 0.007 \\
& $-0.526^{* *}$ & & & 24.351 & 0.366 & 0.366 \\
Work-life Balance & $-0.344^{* *}$ & $-0.443^{* *}$ & & 23.611 & 0.519 & 0.153 \\
& $-0.963^{* *}$ & $-1.076^{* *}$ & $-0.193^{* *}$ & 20.017 & 0.537 & 0.018 \\
Performance & $-0.414^{* *}$ & $-0.459^{* *}$ & & 25.625 & 0.372 & 0.372 \\
/Appreciated & $-0.882^{* *}$ & $-0.917^{* *}$ & & 13.126 & 0.55 & 0.178 \\
Development or & $-0.618^{* *}$ & & 0.143 & 8.278 & 0.559 & 0.009 \\
Career & $-0.404^{* *}$ & $-0.451^{* *}$ & & 23.645 & 0.357 & 0.357 \\
Opportunities & $-1.136^{* *}$ & $-1.222^{* *}$ & & 16.059 & 0.518 & 0.159 \\
\hline
\end{tabular}

${ }^{* * *} \mathrm{p}<0.001,{ }^{* *} \mathrm{p}<0.01,{ }^{*} \mathrm{p}<0.05$. 
Table 7. The moderating effect of interactional justice on relation of total rewards and TI

\begin{tabular}{|c|c|c|c|c|c|c|}
\hline & Step one & Step two & Step three & $\mathrm{F}$ & $\mathrm{R} 2$ & D R2 \\
\hline & $-0.470^{* *}$ & & & 19.258 & 0.285 & 0.285 \\
\hline & $-0.218^{* *}$ & $-0.620^{* *}$ & & 17.327 & 0.521 & 0.234 \\
\hline \multirow[t]{3}{*}{ Remuneration } & $-0.907^{* *}$ & $-1.379^{* *}$ & $-0.216^{* *}$ & 14.914 & 0.579 & 0.058 \\
\hline & $-0.546^{* *}$ & & & 20.41 & 0.305 & 0.305 \\
\hline & $-0.255^{* *}$ & $-0.610^{* *}$ & & 19.058 & 0.59 & 0.289 \\
\hline \multirow[t]{3}{*}{ Welfare } & $-1.311^{* *}$ & $-1.635^{* *}$ & $-0.324^{* *}$ & 15.499 & 0.634 & 0.044 \\
\hline & $-0.526^{* *}$ & & & 24.351 & 0.366 & 0.366 \\
\hline & $-0.250^{* *}$ & $-0.574^{* *}$ & & 23.465 & 0.597 & 0.231 \\
\hline \multirow[t]{2}{*}{ Work-life Balance } & $-1.025^{* *}$ & $-1.337^{* *}$ & $-0.232^{* *}$ & 22.389 & 0.623 & 0.026 \\
\hline & $-0.593^{* *}$ & & & 25.625 & 0.372 & 0.372 \\
\hline Performance & $-0.301^{* *}$ & $-0.569^{* *}$ & & 22.829 & 0.609 & 0.237 \\
\hline /Appreciated & $-1.009^{* *}$ & $-1.259^{* *}$ & $-0.212^{* *}$ & 12.75 & 0.63 & 0.021 \\
\hline Development or & $-0.618^{* *}$ & & & 23.645 & 0.357 & 0.357 \\
\hline Career & $-0.308^{* *}$ & $-0.579^{* *}$ & & 14.98 & 0.604 & 0.247 \\
\hline Opportunities & $-1.328^{* *}$ & $-1.692^{* *}$ & $-0.319^{* *}$ & 11.826 & 0.638 & 0.034 \\
\hline
\end{tabular}

${ }^{* * *} \mathrm{p}<0.001,{ }^{* *} \mathrm{p}<0.01,{ }^{*} \mathrm{p}<0.05$.

Table 8 . Results of the hypothesis test

\begin{tabular}{|c|c|c|}
\hline & Hypothesis & Result \\
\hline H1 & Remuneration is negatively correlated with employees' TI; & Support \\
\hline $\mathrm{H} 2$ & Welfare is negatively correlated with employees' TI; & Support \\
\hline H3 & Work-life Balance is negatively correlated with employees' TI; & Support \\
\hline $\mathrm{H} 4$ & Performance/Appreciated is negatively correlated with employees' TI; & Support \\
\hline H5 & Development or Career Opportunity is negatively correlated with employees' TI. & Support \\
\hline H6-1 & Distributive justice negatively moderates the effect of remuneration to employees' TI; & Support \\
\hline H6-2 & Distributive justice negatively moderates the effect of welfare to employees' TI; & Support \\
\hline H6-3 & Distributive justice negatively moderates the effect of work-life balance to employees' TI; & Support \\
\hline H6-4 & Distributive justice negatively moderates the effect of performance/ appreciated to employees' TI; & Support \\
\hline H6-5 & Distributive justice negatively moderates the effect of development or career opportunity to employees' TI. & Support \\
\hline H6-6 & Process justice negatively moderates the effect of remuneration to employees' TI; & $\begin{array}{c}\text { Not } \\
\text { support }\end{array}$ \\
\hline H6-7 & Process justice negatively moderates the effect of welfare to employees' TI; & $\begin{array}{c}\text { Not } \\
\text { support }\end{array}$ \\
\hline H6-8 & Process justice negatively moderates the effect of work-life balance to employees' TI; & Support \\
\hline H6-9 & Process justice negatively moderates the effect of performance/ appreciated to employees' TI; & $\begin{array}{c}\text { Not } \\
\text { support }\end{array}$ \\
\hline H6-10 & Process justice negatively moderates the effect of development or career opportunity to employees' TI. & Support \\
\hline H6-11 & Interactional justice negatively moderates the effect of remuneration to employees' $\mathrm{TI}$; & Support \\
\hline H6-12 & Interactional justice negatively moderates the effect of welfare to employees' TI; & Support \\
\hline H6-13 & Interactional justice negatively moderates the effect of work-life balance to employees' $\mathrm{TI}$; & Support \\
\hline H6-14 & Interactional justice negatively moderates the effect of performance/ appreciated to employees' TI; & Support \\
\hline H6-15 & Interactional justice negatively moderates the effect of development or career opportunity to employees' TI. & Support \\
\hline
\end{tabular}


After examining the reliability and validity of the questionnaire, we examined the correlation relationship between the variables, and then did regression analysis between the independent variables and the dependent variable and analyzed moderate variable effect, completed the examination of hypothesis proposed. The hypothesis testing results are shown in Table 8 .

\section{Discussion}

\subsection{Implication}

Empirical analysis results show that the first five hypothesis proposed, that is remuneration, welfare, work-life balance, performance or appreciated and development or career opportunity these five components of total rewards, have a significant negative correlation with employee turnover intention. However, compared the regression models of five dimensions of total rewards and turnover intention, the Beta coefficients are similar but different, so their negative role to turnover intention different in level. The most negative related role is development or career opportunity, followed by performance or appreciated, then welfare, and work-life balance, and last is remuneration.

The core employees in the Pearl River Delta have their own unique value and clear pursuit. Their purposes of work are not only to make money, but also want to show their expertise and get successful career. They focus on the realization of their own value, and expect to be recognized by society. Tan (2007) found in the study on the total rewards system design for knowledge workers, that employees prefer the inward pay. It is consistent with the results of our study.

Secondly, we tested the regulatory effect of organizational justice hypotheses proposed in this study through hierarchical regression analysis method. The results show that the organizational justice (distribution justice, process justice and interactional justice) has significant negative moderate effect between total rewards (remuneration, welfare, work-life balance, performance or appreciated and development or career opportunity) and employees' turnover intention. While process justice has significant negative moderate effect only on work-life balance and development or career opportunity to turnover intention, but on remuneration, welfare and performance or appreciated to turnover intention, the negative moderate effect is not significant. Zhang et al (2003) pointed out that the internal justice has important negative correlated effect on managers' turnover. Jiang (2007) also supposed distributive justice and process justice have significant effect on organizational commitment and turnover intention by perceived organizational support.

Combined with the PRD status quo and return visit we found, employees' requirements for process justice are merely about the compensation management approach. However, the remuneration, welfare, and performance are often formulated according to the relevant laws and industry standards. Most enterprises already have the related management practices and effective means of implementation, so the employees value less on the process. It is consistent with the research findings that process justice doesn't has significant effect on the negative correlation of remuneration, welfare, and performance or appreciated to turnover intention. Therefore, from theoretical and practical views, the adjustment effect of organizational justice on the relation between total rewards and employee turnover intention are supported.

Our finding suggests the ways about how to take advantage of the pay system to motivate and retain the core employees:

1) Implement diversified and flexible pay and benefits system. In the demand structure of the core employees at the present stage, the proportion of the survival and security needs has been dwindling. Compensation management embodies higher humane care, and forms become more and more abundant.

2) Develop employee promotion and career growth planning. Job promotion and career growth can meet the self-actualization needs of employees. Promotion opportunities and adequate training offered by companies can meet employees' demand. Employees recognize that only by constantly learning new knowledge, they could adapt to the increasingly rapid update. Therefore, it is very important that whether companies provide the opportunity for learning.

3) Create relaxed working environment. While attaching the career development of knowledge workers, enterprises should create a relaxed working environment for employee, such as job autonomy, flexible working system and encourage innovation.

4) Provide a fair pay system. Although due to the different ability of the employees, the contribution to the enterprise will be different, but it must be reasonable. For distributive justice, it needs to establish a scientific pay system firstly. On the one hand, the remuneration should be paid in accordance with the employees' job and scientific performance design; On the other hand, it should follow the rules of the 
market economy, avoid large difference from similar comparable positions in society. At last, at respect of process justice, companies should improve employees' participation system, reducing the resistance of reform implementation, and establish of monitoring and complaint system.

\subsection{Conclusion}

In conclusion, this study confirms the effect of total rewards to reduce the turnover intention, and the results highlight the importance of development/ career opportunity and performance/ appreciated, which could retain the core employees. Also, the results suggest that distribute and interactional justice of organization could moderate the rewards effect on employees' turnover. We hope this study can encourage others to discuss how and the way that total rewards affect the turnover intention more closely.

\section{References}

Adams, J. S. (1965). Inequity in social exchange. Advances in Experimental Social Psychology, 2, 267-299. http://dx.doi.org/10.1016/S0065-2601(08)60108-2

Armstrong, M., \& Stephens, T. (2005). Handbook of Employee Reward Management and Practice. Kogan Page, London.

Arthur, J. B. (1994). Effects of human resource systems on manufacturing performance and turnover. Academy of Management Journal, 37(3), 670-687. http://dx.doi.org/10.2307/256705

Batt, R. (2002). Managing customer services: Human resource practices, quit rates, and sales growth. Academy of Management Journal, 45(3), 587-597. http://dx.doi.org/10.2307/3069383

Bentein, K., Vandenberghe, C., Vandenberg, R., \& Stinglhamber, F. (2005). The role of change in the relationship between commitment and turnover: a latent growth modeling approach. Journal of Applied Psychology, 90(3), 468. http://dx.doi.org/10.1037/0021-9010.90.3.468

Bies, R. J., \& Moag, J. F. (1986). Interactional justice: communication criteria of fairness. In Lewicki, R. J., Sheppard, B. H., \& Bazerman, M. H. (Eds.), Research on negotiations in organizations. Greenwhch, CT: JAL.

Branham, L. (2001). Keeping the people who keep you in business: 24 ways to hang on to your most valuable talent. AMACOM Div American Mgmt Assn.

Chen, H. M., \& Hsieh, Y. H. (2006). Key Trends of the Total Reward System in 21st Century. Compensation and Benefits Review, 38(8), 64-70. http://dx.doi.org/10.1177/0886368706292542

Dalton, D. R., \& Todor, W. D. (1979). Turnover turned over: An expanded and positive perspective. Academy of Management Review, 225-235.

Danehower, C., \& Lust, J. A. (1996). How aware are employees of their benefits? Findings from two companies. Benefits Quarterly, 12(4), 57.

Egan, J. (2011). Strategic rewards and total rewards. The Chartered Institute of Personnel and Development. Retrieved March 12, from http://www.cipd.co.uk

Eikhof, D. R., Warhurst, C., \& Haunschild, A. (2007). Introduction: What work? What life? What balance? Critical reflections on the work-life balance debate. Employee Relations, 29(4), 325-333. http://dx.doi.org/10.1177/0886368706292542

Eisenberger, R., \& Huntington, R., Hutchison, S., \& Sowa, D. (1986). Perceive organizational support. Journal of Applied Psychology, 71(3), 500-507. http://dx.doi.org/10.1037/0021-9010.71.3.500

Gabris, G. T., \& Ihrke, D. M. (2001). Does performance appraisal contribute to heightened levels of employee burnout? The results of one study. Public Personnel Management, 30(2), 157-172.

Giancola, F. L. (2009). Is total reward a passing fad? Compensation and Benefits Review, 41(4), 29-35. http://dx.doi.org/10.1177/0886368709337926

Gouldner, A. W. (1954). Patterns of Industrial Bureaucracy. New York: Free Press.

Guthrie, J. P. (2001). High-Involvement Work Practices, Turnover, and Productivity: Evidence from New Zealand. Academy of Management Journal, 44(1), 180-190. http://dx.doi.org/10.2307/3069345

Hackman, J. R., \& Oldham, G. R. (1980). Work Redesign. Addison Wesley Publishing Company.

Halaby, C. N. (1986). Worker attachment and workplace authority. American Sociological Review, 634-649. http://dx.doi.org/10.2307/2095489 
He, H. T., Yuan, Y. Z., \& Peng, J. S. (2011). Does Investment in Employee Development Pay off? The Impact of Developmental Human Resources Practices on Knowledge Sharing Behavior and Turnover Intention. Management Review, 1(23), 75-85.

Heneman, R. L., \& Ledford Jr, G. E. (1998). Competency pay for professionals and managers in business: A review and implications for teachers. Journal of Personnel Evaluation in Education, 12(2), 103-121. http://dx.doi.org/10.1023/A:1008076926413

Jiang, C. Y. (2007). Relation among Employees' justice, organizational commitment and turnover intention: empirical research of perceived organizational support as the mediated variable. Economic Scienc, 6 .

Leventhal, G. S. (1980). What should be done with equity theory? In Gergen, K. J., Greenberg, M. S., \& Willis, R. W. (Eds.), Social exchange: Advances in equity and research (pp. 27-55). New York: Plenum. http://dx.doi.org/10.1007/978-1-4613-3087-5_2

Liden, R. C. (1996). Social exchange in organizations: Perceived organizational support, leader-member exchange, and employee reciprocity. Journal of Applied Psychology, 81(3), 219-227. http://dx.doi.org/10.1037/0021-9010.81.3.219

Liu, A. D. (2004). Exploration of Total Rewards System. Human Resource Development of China, 3, 20-22.

Liu, X. (2005). From Compensation to Work Experience- Compensation management of IBM and other famous enterprises. Human Resource Development of China, 6, 62-73.

Ludlow, A., \& Farrell, A. (2010). Making total rewards work. Strategic HR Review, 9(6), 49.

Muchinsky, P. M., \& Morrow, P. C. (1980). A multidisciplinary model of voluntary employee turnover. Journal of Vocational Behavior, 17(3), 263-290. http://dx.doi.org/10.1016/0001-8791(80)90022-6

Nazir, T., Shah, S. F. H., \& Zaman, K. (2012). Literature review on total rewards: An international perspective. African Journal of Business Management, 6(8), 3046-3058.

Noor, K. M. (2011). Work-Life Balance and Intention to Leave among Academics in Malaysian Public Higher Education Institutions. International Journal of Business and Social Science, 2(11), 240-248.

Rhoades, L., \& Eisenberger, R. (2002). Perceived organizational support: A review of the 1iterature Journal of Applied Psychoanalysis, 87(4), 698-714.

Tang, L. F., \& Zeng, X. R. (2007). Design of Total Rewards System of Knowledge-based Employees. Legal System and Society, 2, 541-542.

Thibaut, J., \& Walker, L. (1975). Procedural Justice: A psychological analysis. Hilsdale, NJ: Edbaum.

Tropman, J. E. (2002). The compensation solution: how to develop an employee-driven rewards system (Vol. 17). Shanghai: Jiao Tong University Press.

Yang, G. S. (1993). Social Orientation of Chinese: A Social interactional perspective. In Yang, G. S., \& Yu, A. B. (Eds.), The mind and behavior of Chinese: Theory and methodology (pp. 87-141). Taipei: Guiguan Press.

Yao, X. G., \& Fang, Y. C. (2005). Empirical Study on Effect of Hi-tech Enterprise' Salary System. Technological Economy, 11, 58-59.

Zhang, J. Q., \& Wang, F. (2003). Empirical Research on the cause of Private Enterprise Managers' drain -Analysis of Guangdong Private Enterprise Managers Turnover Intention. Management World, 9.

Zhang, L., \& He, J. D. (2001). Core Employees Create Core Competition. Human Resource Development of China, 3, 50-54.

Zhang, M., \& Zhang, D. (2007). Factors Affecting Employees' Turnover Intension: A Quantitive Study of Some New Variables. Management Revie, 4(19).

Zhao, J. J., \& Shi, N. (2006). Research on Motivation of Core Employees. Industrial Technology \& Economy, 8 , $26-28$.

Zhou J., \& Yang, L. Q. (2012). Study on Total Compensation Optimization Based on Employees' Needs. Industrial Engineering and Management, 17(3), 108-116.

Zingheim, P. K., \& Schuster, J. R. (2003). Competencies and rewards: substance or just style? Compensation \& Benefits Review, 35(5), 40-44. http://dx.doi.org/10.1177/0886368703256932

Zingheim, P. K., \& Schuster, J. R. (2006). Career Directions for Total Rewards Professionals. Compensation and 
Benefits Review, 38(3), 18.

\section{Copyrights}

Copyright for this article is retained by the author(s), with first publication rights granted to the journal.

This is an open-access article distributed under the terms and conditions of the Creative Commons Attribution license (http://creativecommons.org/licenses/by/3.0/). 